\title{
CONSISTENCY OF THE INSTRUCTIONS FOR THE USE OF PROSPECTIVES FOR DETERMINING THE AREA OF A PARALLELA AND TRIANGLE AREA FOR STUDENTS OF SDN 6 MATARAM
}

\author{
Ketut Sarjana $^{1}$, Endang P. Handayani ${ }^{2}$, Siti Aminah $^{3}$, Nuraini ${ }^{4}$ \\ ${ }^{1}$ Pendidikan Matematika, FKIP, Universitas Mataram, Mataram, Indonesia \\ ${ }^{2,3,4}$ SDN 6 Mataram, Indonesia
}

\section{Article Info}

Article history:

Received: 26-05-2021

Revised: 06-08-2021

Published: 30-09-2021

\section{Keywords:}

Math props

Instructions for using props

Area of a parallelogram

Area of triangle

ABSTRACT

The approach used in this research is a quantitative approach with a quasi-experimental research design. The purpose of this study was to test the consistency and effectiveness of the instruction manual for determining the area of a parallelogram and the area of a triangle for students of SD 6 Mataram. To achieve this goal, tools and instructions for use were used in learning for the $3^{\text {th }}$ grade students of SDN 6 Mataram and divided into 3 classes. Because the research was conducted during the COVID-19 pandemic, the media was designed to be a learning video that describes the use of props and their operational guidelines are narrated in the video. The video that contains the use of the tool is considered very in accordance with the instructions for use props. The results of the evaluation showed that there was no significant difference in the mean scores of the three pairs of classes (significance level $5 \% t_{h}<t_{\text {table }}=2,0002$ ). On the other hand, the completeness obtained by students in each class is $>80 \%(\mathrm{KKM}=70)$. This means that there is complete student learning about the area of a parallelogram and the area of a triangle. Thus, it can be concluded that the teaching aids for determining the area of a parallelogram and the area of a triangle and the instructions for use are consistently effective in helping students achieve complete learning on the material for the area of a parallelogram and the area of a triangle.
\end{abstract}

This is an open access article under the CC BY-SA license.

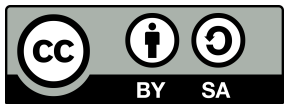

\section{Corresponding Author:}

Ketut Sarjana,

Mathematics Education Study Program, Faculty of Teacher Training and Education, Universitas Mataram, Jl. Majapahit, No. 62, Mataram, Indonesia.

Email: kssarjanafkip@gmail.com

\section{INTRODUCTION}

It is difficult for elementary school students to learn geometry, because the geometry material is very abstract, while elementary school students think that their way of thinking is still at the level of concrete operations. This is in line with what was revealed by Piaget in Hudoyo that elementary school students think that their thinking is still at the stage of concrete operations (Affandi, Saputra, \& Husniati, 2020). In this regard, if elementary school students learn geometry, they should be faced with suitable concrete objects or objects, objects manipulated by children to build concepts or principles of geometry being studied. This is in accordance with Brunner's statement in Nyimas Aisyah stating that in the learning process, children should be given the opportunity to manipulate objects that are specifically designed and can be tampered with by students 
in understanding mathematical concepts.

Students learn by using teaching aids, students will actively try or tinker with these props. This view is in accordance with the motto quoted by Ruseffendi which says that I hear so I forget, I see so I know, I do so I understand. In line with what was stated by Brunner that in the enactive stage students were directly involved in manipulating objects. From the regularity of the objects observed, students can abstract the concepts and principles learned. This is in accordance with the constructivist view which states that students must build their own meaning from their experiences and interactions with others. This is the reason why teaching mathematics, especially teaching geometry in elementary schools, requires visual aids and aids. With this media students feel happy, motivated, interested and have a positive attitude towards teaching mathematics (Ariesca, Dewi, \& Setiawan, 2021).

There have been many writings that mention that the use of teaching aids in mathematics learning causes learning to be effective. One of the things revealed by Brown (1970) that the media used by students or teachers properly can affect the effectiveness of the teaching and learning process (Satriami, Darmiany, \& Saputra, 2021). However, the statement did not mention how the procedure for using the media could be carried out in order to achieve its objectives. Using props to determine the area of parallelograms and triangles the results are different from one another even though the props used are the same for the same material and at the same level. This means that teachers need other instruments so that the message conveyed is the same. That is why we need a manual for using props. The problem now is "What is the consistency and effectiveness of the instructions for using visual aids to determine the area of a parallelogram and a triangle area for students of SD 6 Mataram?

The purpose of this study was to determine the consistency and effectiveness of the implementation of the instructions for using teaching aids to determine the area of a parallelogram and the area of a triangle for elementary school students in the city of Mataram. The selection of the right subject matter content, which can be understood based on the concrete experiences of students, makes teaching aids promising as media and learning resources that are suitable for elementary students. Through the tool students can see directly the existing regularities, so that students are more successful in their learning. On the other hand, through teaching aids, students learn through doing and actively learning both individually and in groups, because the props used can be manipulated by tinkering with them, such as being touched, held, moved or installed and disassembled. In order for the use of this teaching aid to be optimal, it is necessary to use instructions in operating it. In connection with this, Sarjana, et al. (2018) has conducted research on the construction of teaching aids and operational guidelines. The results of the study stated that the tool that was constructed was very valid. So, it can be understood that student learning can be effective depending on the means used. This is in line with Sudjana's learning achievement achieved by students influenced by external factors. Similarly, Slameto's learning achievement is influenced by the use of learning media. Every abstract concept in mathematics that is newly understood by children needs to be immediately given reinforcement so that it settles, sticks and is long-lasting so that it becomes his/her own in the pattern of thought and pattern of action. For this purpose, it is necessary to learn through doing and understanding, not just memorizing or remembering facts which are of course easy to forget and difficult to acquire. This view is in accordance with the motto quoted by Ruseffendi which says that I hear so I forget, I see so I know, I do so I understand (Nyoman, Astuti, \& Setiawan, 2021).

The slogan I see, I know, implies to educators that in every learning process mathematics is expected to use media that can be seen. Because by looking at the abstract concept of geometry can be understood easily. Then I did it and I understand that it inspires that in the learning process of mathematics students are expected to do something. Through the way of doing students will feel what is learned is meaningful to him. This will be a driving force for students to find out about what is being studied. For this reason, the visual media used to expedite the original process are in the form of items that can be manipulated, namely by being touched, held, moved or disassembled. On the other hand, the tools referred to are instructions for using the props. Instructions for use of the tool serve to explain how.

\section{RESEARCH METHOD}

In this study, applying geometry learning aids about determining the area of a parallelogram, the area of a triangle, which is equipped with operational guidelines. Instructions for use are made to make it easier for teachers to use the media.

Props and instructions for use have been made which are the results of research conducted on by 
(2018). The results showed that the tools that were constructed and the instructions for their use were feasible and valid. The feasibility of the tool was validated by 9 people consisting of 3 experts and 6 practitioners. As research subjects, grade VI students where learning uses online learning, namely using WhatsApp because the research was carried out during the COVID 19 pandemic and the three classes have almost the same abilities. In carrying out learning, teachers are assisted by designing teaching aids about determining the area of parallelograms and triangles in the form of learning videos. Regarding the operational guidelines of the teaching aids, it is narrated in the video and adapted to the instructions for using the teaching aids that have been prepared.

To obtain data about the certainty of the instructions for using the tool appearing in learning, an observation tool is used. The description of this tool includes exploring the prerequisites of knowledge, showing the elements of the shape to be searched for the area of the area, conducting experiments in cutting and assembling and looking for the relationship of the elements of the flat shape to conclude the formula for the area being searched. The test is used to obtain data on student achievement regarding the area of parallelograms and triangles.

The data analysis technique used in the study is a descriptive technique, namely matching because the differentiated sample is limited and the significance level is 0.05 . Furthermore, to determine the effectiveness of learning using video, a completeness test is used, namely students are said to be complete if $80 \%$ more than all students get a minimum score equal to the minimum completeness score (KKM).

$$
\frac{\overline{X_{1}}-\overline{X_{2}}}{\sqrt{\frac{\left(n_{1}-1\right) s_{1}^{2}+\left(n_{2}-1\right) s_{2}^{2}}{\left(n_{1}+n_{2}\right)-2}\left(\frac{1}{n_{1}}+\frac{1}{n_{2}}\right)}}
$$

\section{RESULT AND DISCUSSION}

Before the implementation is carried out, a video is shown. The video playback is intended to find information about the match between the narration in the video and the points of the operational guidelines. Video observations were carried out by 9 senior elementary school teachers, 3 each from 3 regions of Cakranegara, Mataram and Ampenen.

Data from observations from 9 elementary school teachers after being processed showed that the instructions for using teaching aids were very appropriate after being narrated in the learning video. On the other hand, the data obtained from the results of students' ability tests about the area of a parallelogram and the area of a triangle are shown in the following table:

Table 1. The results of the t-test of three pairs of classes

\begin{tabular}{lcccccc}
\hline & $\mathrm{A}_{1}$ & $\mathrm{~B}_{1}$ & $\mathrm{~A}_{1}$ & $\mathrm{C}_{1}$ & $\mathrm{~B}_{1}$ & $\mathrm{C}_{1}$ \\
\hline Mean & 78,61 & 77,21 & 78,61 & 78,96 & 77,21 & 78,96 \\
Variance & 111,52 & 91,56 & 111,52 & 203,19 & 91,56 & 203,19 \\
Observation & 31 & 30 & 31 & 32 & 30 & 32 \\
df & 59 & & 61 & & 60 & \\
t-Stat & $\mathbf{0 , 5 4 1}$ & & $\mathbf{- 0 , 1 1 2}$ & & $\mathbf{- 0 , 5 6 4}$ & \\
t-Critical & 2,000 & & 1,999 & & 2,000 & \\
\hline
\end{tabular}

Learning mathematics means learning about facts, concepts, principles and operations. Facts concerning postulates or axioms, concepts concerning understanding such as definitions and principles concerning theorems, properties, propositions or formulas. This mathematical stuff is an abstract thing. This is in accordance with what was revealed by as in the previous description.

It is understood that elementary school students are at the stage of concrete thinking. So, if the teaching of geometry such as the principle of the area of parallelograms and triangles is taught without using the media, it will clearly be problematic. As a result, teaching mathematics at this age requires the use of intermediaries, which allows geometry to communicate with elementary school students (Usriyah \& Prayogo, 2018). The intermediary here is a teaching aid that is designed in such a way that students can observe, feel and try, find and then reason in order to build geometric principles. The principle of geometry in this study concerns the formula for the area of a parallelogram and the area of a triangle. The teaching aids used by different teachers in accelerating the learning process with the same topic, are not necessarily the same message. So that the visual media needs to be accompanied by instructions for use to dismiss this statement (Sumarno, Gimin, \& Nas, 2017). 
In this study, implement geometry teaching aids for class VI students equipped with instructions for use. It has been described above that the implementation of research during the COVID-19 pandemic so that the choice of modifying the tool with learning videos is the most accurate choice. The implementation of teaching aids through videos is carried out by the teachers in several steps such as distributing the video, then the students observe, doing assignments, clarification from the teacher, completing the exercises set in the student worksheets, and the last one being a test. From result implementation has obtained the results of data analysis that $\left|t_{h}\right|<t_{\text {table }}=2,0002$. This means that the value group pairs obtained by the average score are not significantly different at the 0.05 significance level. This means that there is no convincing difference in performance. So, by using the instructions for using the props about determining the area of the line and the area of the triangle, the message conveyed is the same so that the tools used are consistent.

In addition, the use of teaching aids makes learning effective because learning mastery has been obtained above $80 \%$. This means that more than $80 \%$ of all students get a minimum score equal to the KKM of 70. This quantity indicates that there has been a change in better learning achievement. This means learning is effective. This is in accordance with Brown (1970) in Asra (2007), mentions that the media used by students or teachers properly can affect the effectiveness of the teaching and learning process. From these results, it shows that students learn through visual aids, abstract concepts can be observed by students through impressions. On the other hand, through the existing commands, students can do trying activities, not just remembering.

The use of teaching aids in learning causes learning to be effective. One of the things revealed by Brown (1970) in Asra (2007), mentions that the media used by students or teachers properly can affect the effectiveness of the teaching and learning process. So this is in accordance with the motto quoted by Ruseffendi which states that I hear so I forget, I see so I know, I do so I understand (Russefendi, 1996).

The slogan I see then I know implies that in every mathematics learning process it is expected to use media that can be seen. Because by looking at abstract geometric concepts can be understood easily. Then I did it and I understand that it inspires that in the process of learning mathematics students are expected to do something. Through how to do students will feel what is learned is meaningful to him. This will be an incentive for students to find out about what is being studied. On the other hand, visual aids with operational instructions for their use are more optimal, because the instructions for using these tools serve to explain how the tools can be used by users who do not understand them uniformly. So that the overall use of teaching aids equipped with instructions for use causes learning to determine the formula for the area of a parallelogram and determine the area of a triangle to be consistent and effective.

\section{CONCLUSION}

The results of the study concluded that through the application of teaching aids in learning to determine the formula for the area of a parallelogram and the area of a triangle to be effective. This can be seen from the completeness achieved for each class in Mataram City is more than $80 \%$. By utilizing the instructions for using learning tools to be consistent because it has been obtained a test of two different values mean did not differ significantly. It can be seen that $<=2,0002$. So by using teaching aids equipped with instructions for use, learning becomes consistent and effective.

\section{REFERENCES}

Affandi, L. H., Saputra, H. H., \& Husniati, H. (2020). Apakah Tingkat Kebahagiaan Bisa Menjelaskan Hasil Belajar Siswa Sekolah Dasar? PROGRES PENDIDIKAN, 1(3), 168-176. doi:10.29303/prospek.v1i3.21

Ariesca, Y., Dewi, N. K., \& Setiawan, H. (2021). ANALISIS KESULITAN GURU PADA PEMBELAJARAN BERBASIS ONLINE DI SEKOLAH DASAR NEGERI SE-KECAMATAN MALUK KABUPATEN SUMBAWA BARAT. PROGRES PENDIDIKAN, 2(1), 20-25. doi:10.29303/prospek.v2i1.86

Asra, A., Darmawan, D., \& Riana, C. (2007). Komputer dan Media Pembelajaran di SD. Jakarta: Dirjen Dikti Departemen Pendidikan Nasional.

Nyoman, N., Astuti, S., \& Setiawan, H. (2021). Pengaruh Model Concept Sentence Berbantuan Flash Card Correlation of Teacher Personality Competence With Discipline of Student Learning in Grade 5 At $\mathrm{Sd}$ Negeri Gugus I Lopok Academic Year 2020 / 2021. Renjana Pendidikan Dasar, 1(1), 35-43.

Russefendi, E. (1996). Pendidikan Matematika III Modul 1-9. Jakarta: Depdikbud.

Sarjana, K., Sridana, N., \& Turmuzi, M. (2018). Disain Media Peraga Dan Bantu Pembelajaran Geometri Bagi Siswa Sekolah Dasar Kelas Tinggi. Jurnal Ilmiah Profesi Pendidikan, 3(2), 176-182. 
Satriami, W., Darmiany, \& Saputra, H. H. (2021). Hubungan Kompetensi Kepribadian Guru Dengan Disiplin Belajar Siswa Kelas V Sd Negeri Gugus I Lopok Kota Sumbawa Correlation of Teacher Personality Competence With Discipline of Student Learning in Grade 5 At Sd Negeri Gugus I Lopok Academic Year 2020 / 20. Renjana Pendidikan Dasar, 1(1), 30-34.

Sumarno, Gimin, \& Nas, S. (2017). Dampak Biaya Kuliah Tunggal Terhadap Kualitas Layanan Pendidikan. Kelola: Jurnal Manajemen Pendidikan, 4(2), 184-194.

Usriyah, L., \& Prayogo, M. S. (2018). Problematika Implementasi Pembelajaran Tematik Integratif di Lembaga Pendidikan Dasar Islam: Studi Kasus di Madrasah Ibtidaiyah Negeri (MIN) Garahan Jember Jawa Timur. TADRIS: Jurnal Pendidikan Islam, 13(2), 34-43. doi:10.19105/tjpi.v13i2.1678 